\title{
Penerapan Metode Taguchi untuk Meningkatkan Kualitas Bata Ringan pada UD. XY Malang
}

\section{Application of the Taguchi Method to Improve the Quality of Lightweight Bricks at UD. XY Malang}

\author{
Putri Halimah $^{1}$, Yurida Ekawati ${ }^{*}$ \\ ${ }^{1}$ Program Studi Teknik Industri, Universitas Ma Chung, Villa Puncak Tidar Blok N No. 1, Dau, Malang 65151, \\ Indonesia
}

Diterima: 7 Agustus, 2019 / Disetujui: 27 Januari, 2020

\begin{abstract}
Light brick compressive strength produced by UD. XY has a very high variation because there is no standard composition of raw materials. This research is carried out to design an improvement or quality improvement for light brick products at UD. XY. Quality improvement is on increasing the compressive strength of light brick with optimal composition. Quality improvement is conducted using the experimental design of the Taguchi method to obtain an optimal composition combination. The orthogonal array notation used is $L_{9}\left(3^{4}\right)$ with material control factors in the form of water $(A)$, cement $(B)$, and sand $(C)$. Data processing is done by calculating ANOVA on average values and SNR with larger better classification. The classification is chosen because of the greater the compressive strength of the light brick the higher the quality of the light brick. This ANOVA calculation is carried out to find out which factors significantly influence the light brick compressive strength. The test conducted to determine the quality of light brick is a concrete compressive strength test carried out using the Compression Machine. Based on the results of data processing, a comparison of the optimal composition of water: cement: sand is 1: 2.5: 4. The confirmation experiment proves that the compressive strength of the composition is robust.
\end{abstract}

Keywords: Quality improvement, Lightweight brick, Taguchi, Compressive strength.

\begin{abstract}
ABSTRAK
Kuat tekan bata ringan yang dihasilkan UD. XY memiliki variasi yang sangat tinggi karena belum adanya standar komposisi bahan baku. Pelitian ini dilakukan untuk merancang suatu perbaikan atau peningkatan kualitas terhadap produk bata ringan di UD. XY. Peningkatan kualitas adalah pada peningkatan kuat tekan dari bata ringan dengan komposisi optimal. Peningkatan kualitas dilakukan dengan menggunakan desain eksperimen metode Taguchi untuk mendapatkan kombinasi komposisi yang optimal. Adapun notasi orthogonal array yang digunakan adalah $\mathrm{L}_{9}\left(3^{4}\right)$ dengan faktor kontrol material berupa air (A), semen (B), dan pasir (C). Pengolahan data dilakukan dengan melakukan perhitungan ANOVA terhadap nilai rata-rata dan SNR dengan klasifikasi larger the better. Klasifikasi tersebut dipilih karena semakin besar kuat tekan dari bata ringan semakin tinggi kualitas bata ringan tersebut. Perhitungan ANOVA ini dilakukan dengan tujuan untuk mengetahui faktor mana saja yang berpengaruh secara signifikan terhadap kuat tekan bata ringan. Pengujian yang dilakukan untuk mengetahui kualitas bata ringan adalah uji kuat tekan beton yang dilakukan dengan menggunakan Compression Machine. Berdasarkan hasil pengolahan data, didapatkan perbandingan kombinasi komposisi air:semen:pasir optimal sebesar 1:2,5:4. Eksperimen konfirmasi membuktikan bahwa kuat tekan dari komposisi tersebut bersifat robust.
\end{abstract}

Kata Kunci: Perbaikan kualitas, Bata ringan, Taguchi, Kuat tekan.

\section{PENDAhUluaN}

Saat ini, dunia industri merupakan salah satu bagian penting untuk pembangunan. Persaingan di dunia industri terutama industri manufaktur kini semakin ketat hal ini menyebabkan semua perusahaan berusaha memberikan kualitas produk yang terbaik bagi para konsumennya. Semua perusahaan bersaing secara ketat agar dapat memikat konsumen. Penawaran yang diberikan tidak hanya mengacu

*email: yurida.ekawati@machung.ac.id 
pada harga yang diberikan, namun kualitas produk juga ditawarkan. Kualitas produk menjadi hal yang harus diutamakan perusahaan dalam mencapai kepuasan konsumen dalam menggunakan produk yang telah dihasilkan. Kualitas merupakan kebalikan dari variabilitas, di mana semakin kecil variabilitas suatu produk maka semakin tinggi kualitas produk tersebut (Montgomery, 2013). Pembangunan yang semakin meningkat di Indonesia memberikan peluang bagi perusahaan yang memproduksi bata ringan. Kebutuhan penggunaan bata ini mendorong munculnya inovasi-inovasi baru dalam pembuatan bata, salah satunya adalah bata ringan yang juga bisa disebut beton ringan. peluang bagi perusahaan yang memproduksi

UD. XY merupakan industri rumahan yang memproduksi bata ringan. Bata ringan dibuat dengan menggunakan bahan baku semen, pasir, air, dan foaming agent. Jenis bata ringan yang diproduksi UD. XY adalah Cellular Lightweight Concrete (CLC) dikarenakan proses pengeringan tidak menggunakan oven melainkan secara alami dengan udara terbuka. Proses produksi bata ringan di UD. XY dikerjakan manual, artinya tidak dikerjakan dengan mesin melainkan dikerjakan oleh manusia. Permasalahan yang muncul adalah pekerja menentukan komposisi bahan baku bata ringan hanya berdasarkan perkiraan. Hal ini dapat memengaruhi variasi kualitas bata ringan dikarenakan tidak ada komposisi yang baku terhadap bata ringan yang diproduksi oleh UD. $\mathrm{XY}$. Komposisi bahan pembuatan dan proses yang tidak baku menyebabkan biaya produksi yang tidak pasti. Berikut merupakan uji tekan awalan pada produk bata ringan:

Tabel 1. Uji Tekan Awalan Produk Bata Ringan

\begin{tabular}{ccccc}
\hline No & $\begin{array}{c}\text { Beban } \\
\text { Tekan } \\
(\mathbf{k N})\end{array}$ & $\begin{array}{c}\text { Konversi } \\
\text { Beban } \\
(\mathbf{k g})\end{array}$ & $\begin{array}{c}\text { Luas } \\
\text { Bidang } \\
\left(\mathbf{c m}^{\mathbf{2}}\right)\end{array}$ & $\begin{array}{c}\text { Kuat } \\
\text { Tekan } \\
(\mathbf{k g} /\end{array}$ \\
$\left.\mathbf{c m}^{2}\right)$
\end{tabular}

Berdasarkan perhitungan kuat tekan bata ringan awal didapatkan standar deviasi sebesar 5,62 dan memiliki varians sebesar 31,68 serta penyimpangannya sebesar $30,059 \%$. Dapat dilihat besarnya variasi pada produk bata ringan dari hasil pengujian uji tekan awal bata ringan sangatlah besar.

Dimensi kualitas terdiri dari kinerja (performance), daya tahan (durability), bukti fisik (tangibles), empati (emphaty), keandalan (reliability), daya tanggap (responsiveness), fitur (features) (Tjiptono, 2012). Kuat tekan bata ringan termasuk dalam dimensi kinerja (performance) dari bata ringan tersebut. Untuk mendapatkan kuat tekan yang optimal dari bata ringan tersebut maka perlu dilakukan desain eksperimen.

Suatu desain eksperimen adalah evaluasi secara serentak terhadap dua atau lebih faktor (parameter) terhadap kemampuannya untuk memengaruhi rata-rata atau variabilitas hasil gabungan dari karakteristik produk atau proses tertentu. Secara efektif dan sesuai secara statistik, level dari faktor kontrol dibuat bervariasi, hasil dari kombinasi pengujian tertentu diamati, dan kumpulan hasil selengkapnya dianalisis untuk menentukan faktor-faktor yang berpengaruh dan tingkatan yang baik, dan apakah peningkatan atau pengurangan tingkatan-tingkatan tersebut akan menghasilkan perbaikan lebih lanjut (Soejanto, 2009). Desain eksperimen merupakan pengaturan pemberian perlakuan terhadap percobaan dengan maksud agar keragaman respon yang ditimbulkan oleh keadaan lingkungan dan keheterogenan bahan percobaan yang digunakan dapat disingkirkan (Gaspersz, 1994).

Metode Taguchi merupakan usaha peningkatan kualitas yang berfokus pada peningkatan rancangan produk dan proses. Sasaran metode tersebut adalah menjadikan produk tidak sensitif terhadap variabel gangguan (noise), sehingga disebut sebagai robust design. Metode ini digunakan dalam perekayasaan dan peningkatan kualitas dengan cara desain eksperimen untuk menemukan penyebab utama yang sangat dominan memengaruhi karakteristik kualitas dalam proses, sehingga variabel karakteristik kualitas dapat dikendalikan. Dengan metode ini diperoleh kombinasi terbaik antara unit produk dan unit proses pada tingkat keseragaman yang tinggi untuk mencapai karakteristik kualitas terbaik 
dengan biaya yang rendah (Soejanto, 2009). Desain eksperimen orthogonal array yang merupakan modifikasi dari desain fractional factorial yang kemudian dilengkapi transformasi respon dalam bentuk Rasio signal terhadap noise ( $\mathrm{S} / \mathrm{N}$ ratio), menjadi penemuan Taguchi yang paling fenomenal. Taguchi telah menawarkan efisiensi eksperimen dalam rangka merekayasa kualitas. Bukannya tanpa kekurangan, metode Taguchi ini tetap memiki risiko kesalahan pengambilan kesimpulan karena banyaknya eksperimen yang terpangkas.

Untuk mengetahui faktor-faktor yang memengaruhi kuat tekan bata ringan dapat digunakan diagram sebab-akibat/diagram atau tulang ikan. Diagram tulang ikan atau fishbone diagram adalah salah satu metode/tool di dalam meningkatkan kualitas. Dikatakan fishbone diagram (tulang ikan) karena memang berbentuk mirip dengan tulang ikan yang kepalanya menghadap ke kanan (Murnawan dan Mustofa, 2014). Diagram sebab akibat merupakan suatu diagram yang menunjukkan hubungan antara sebab dan akibat (Gaspersz, 2001). Diagram ini banyak digunakan dalam perbaikan kualitas seperti perbaikan kualitas produk wafer (Sutiyarno dan Chriswahyudi, 2019).

Terdapat beberapa penelitian optimasi menggunakan metode Taguchi terhadap produkproduk sejenis bata ringan. Metode Taguchi digunakan baik untuk perbaikan kualitas produk maupun desain produk yang optimal. Penelitian sebelumnya telah melakukan optimasi produk menggunakan metode Taguchi terhadap produk beton aerasi ringan dan sekaligus memperhitungkan pengurangan kerugian akibat perbaikan kualitas (Tiartanaya dan Aribowo, 2013). Metode Taguchi juga dilakukan untuk pembuatan batako dengan memanfaatkan lumpur Lapindo (Prasetya, Rahman dan Efranto, 2013). Selain itu studi lain juga melakukan penelitian optimasi produk batako berdasar kuat tekan dan daya serapnya (Sutoni, 2018).

Tujuan dari penelitian ini adalah mengetahui faktor-faktor yang memengaruhi kualitas produk batu bata ringan di UD. XY, dan menemukan cara memperbaiki atau meningkatkan kualitas produksi batu bata ringan dengan menggunakan metode Taguchi. Metode Taguchi dipilih karena dengan metode ini dapat diperoleh desain kombinasi terbaik dari faktorfaktor yang berpengaruh terhadap peningkatan kualitas produk bata ringan dengan eksperimen yang lebih sederhana, dibandingkan apabila menggunakan desain eksperimen full factorial, namun menghasilkan desain produk yang kokoh (robust design). Penyederhanaan jumlah kombinasi ini penting dilakukan karena menggunakan uji yang bersifat merusak (uji tekan) untuk pelaksanaannya. Uji tekan menyebabkan produk yang diuji tidak bisa lagi untuk dipergunakan, sehingga penyederhanaan jumlah eksperimen pada metode Taguchi akan mengurangi biaya.

\section{METODE PENELITIAN}

Penelitian ini dilakukan di salah satu UD di Malang yang memproduksi bata ringan, GRC roster, paving, plavon, dan lain-lain. Penelitian ini dilaksanakan pada bulan Januari 2019 sampai bulan Mei 2019. Bahan baku yang digunakan semen, pasir, air, dan foam agent. Peralatan yang digunakan adalah cetakan dan ember. Gambar 1 adalah diagram alir dari penelitian.

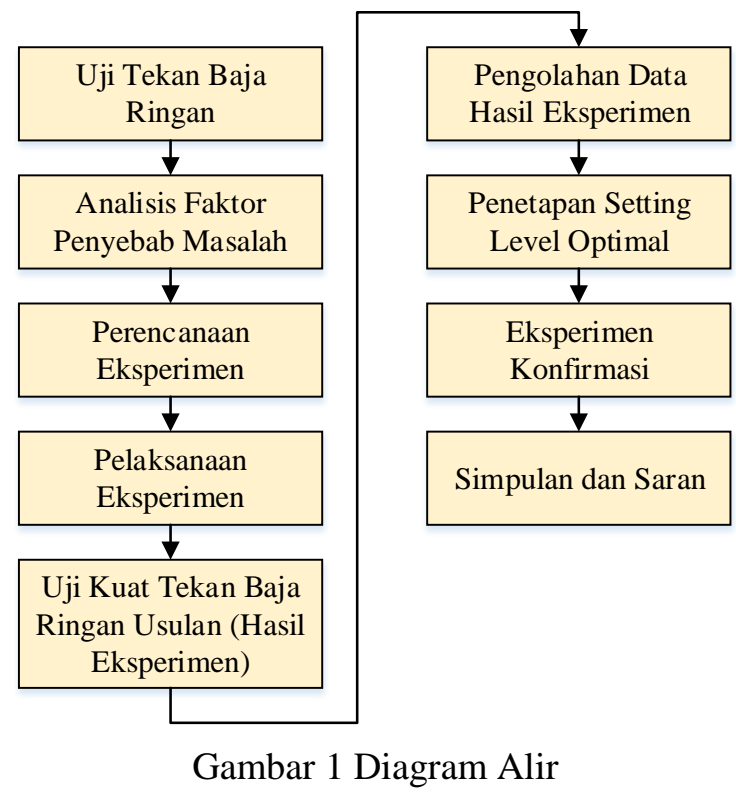

Setelah mengetahui permasalahan dan studi literatur maka dilakukan uji tekan awalan pada bata ringan. Uji kekuatan tekan merupakan aktivitas yang dilakukan untuk mengetahui kekuatan dari sebuah benda yang didapatkan dari nilai kuat tekan dengan prosedur tertentu (Müller et al., 2006). Kuat tekan beton ringan merupakan besarnya beban per satuan luas yang menyebabkan benda uji tekan beton hancur bila dibebani dengan gaya tekan tertentu. Setelah dilakukan uji tekan dilakukan analisis penyebab 
besarnya variasi pada kuat tekan bata ringan menggunakan diagram tulang ikan.

Perencanaan eksperimen dilakukan sebagai tahap awal atau tahap persiapan dalam metode Taguchi. Tahap awal ini merupakan tahap yang sangat penting agar pelaksanaan eksperimen dapat berjalan dengan lancar. Dalam perencanaan eksperimen terdapat beberapa langkah yang harus dilakukan, mulai dari pengumpulan data hingga pembuatan matriks orthogonal array.

Pengumpulan data dilakukan dengan wawancara, dan observasi secara langsung. Wawancara dilakukan dengan kepala produksi. Dari hasil wawancara didapatkan informasi mengenai bahan baku apa saja yang digunakan dalam pembuatan bata ringan. Pengumpulan data selanjutnya dilakukan dengan observasi langsung. Berdasarkan hasil observasi didapatkan informasi mengenai alur produksi dan proses pembuatan pada bata ringan UD. XY.

Selanjutnya dilakukan identifikasi karakteristik kualitas. Identifikasi ini penting untuk dilakukan agar fokus eksperimen dapat lebih terarah. Metode Taguchi memperkenalkan pendekatan $S / N$ ratio untuk meneliti pengaruh faktor noise terhadap variasi yang timbul. Jenis dari $S / N$ ratio tergantung pada karakteristik yang diinginkan, yaitu Small the Better (STB), Larger the Better (LTB), dan Nominal the Best (NTB) (Setyanto dan Lukodono, 2017).

Adapun karakteristik kualitas yang dipilih pada penelitian ini adalah larger the better. Pada penelitian ini, variabel tak bebas adalah kekuatan bata ringan. Kekuatan bata ringan ini dapat diketahui dengan melakukan uji kuat tekan dimana semakin tinggi kuat tekan yang dimiliki oleh bata ringan maka akan semakin baik. Rumus karakteristik kualitas larger the better ditampilkan pada persamaan (1).

$$
S N_{L T B}=-10 \log \left[\frac{1}{n} \sum_{i=1}^{n} \frac{1}{y_{i}^{2}}\right]
$$

Langkah selanjutnya adalah melakukan eksperimen dan melakukan uji kuat tekan terhadap bata ringan hasil eksperimen. Pengolahan data dilakukan dengan menggunakan analisis varians. Analisis varians pada metode Taguchi merupakan suatu metode statistik untuk menginterpretasikan data-data hasil eksperimen (Triawati, 2007). Analisis varians pada metode Taguchi dilakukan dengan langkah perhitungan sebagai berikut (Soejanto, 2009):

1. Perhitungan nilai rata-rata keseluruhan eksperimen

$$
\bar{y}=\frac{\sum y}{n}
$$

2. Perhitungan rata-rata respon masing-masing eksperimen

$$
\overline{\overline{y_{j k}}}=\frac{\sum y_{i j k}}{n_{i j k}}
$$

3. Perhitungan jumlah kuadrat total (total sum of square)

$$
S S_{\text {total }}=\sum y^{2}
$$

4. Perhitungan total sum of square due to mean

$$
S_{m}=n \cdot \overline{y^{2}}
$$

5. Perhitungan total sum of square due to factors

$$
S S_{i}=\left(\sum_{i}\left(n_{i j}\right)\left(\overline{l^{2}}\right)\right)-S_{m}
$$

6. Perhitungan total sum of square due to error

$$
S S_{e}=S S_{\text {total }}-S_{m}-\left(\sum_{i} S S_{i}\right)
$$

7. Perhitungan the mean square

$$
M S_{i}=\frac{S S_{i}}{D F_{i}}
$$

8. Perhitungan $F_{\text {ratio }}$ atau $F_{\text {hitung }}$

$$
F_{\text {ratio }}=\frac{M S_{i}}{M S_{e}}
$$

9. Perhitungan pure sum of square

$$
S S_{i}^{\prime}=S S_{i}-\left(D F_{i} \cdot M S_{e}\right)
$$

10.Perhitungan persen kontribusi 


$$
\rho_{i}=\frac{S S_{i}{ }^{\prime}}{S S_{t}}
$$

Penetapan setting level optimal dilakukan dengan cara melihat pada tabel maupun grafik respon. Setelah mendapatkan setting level optimal maka dilakukan eksperimen konfirmasi.

Eksperimen konfirmasi merupakan eskperimen yang bertujuan untuk melakukan validasi terhadap kesimpulan yang diperoleh selama tahap analisis data hasil eksperimen (Soejanto, 2009). Dalam melakukan eksperimen konfirmasi perlu untuk mengetahui kombinasi optimal dari level dan faktor yang memiliki pengaruh signifikan. Adapun beberapa hal yang perlu untuk diperhatikan dalam melaksanakan eksperimen konfirmasi adalah sebagai berikut (Soejanto, 2009):

1. Memperkirakan nilai rata-rata

Adapun untuk memperkirakan rata-rata ini dihitung dengan menggunakan persamaan (12).

$$
\mu_{p}=\bar{y}+\sum X_{i}-\bar{y}
$$

dimana:

$\mu_{p}: \mu_{\text {prediksi }}$

2. Menghitung interval atau selang kepercayaan untuk nilai perkiraan rata-rata.

Dalam membuat interval kepercayaan perlu untuk dilakukan perhitungan nilai CI dengan menggunakan persamaan (13) dan persamaan (14).

$$
n_{e f f}=\frac{N}{d f}
$$

dimana

$N \quad$ : Jumlah total eksperimen

$d f \quad$ : Jumlah $d f$ dalam perkiraan rata-rata

$$
C I= \pm \sqrt{F_{(\alpha ; v 1 ; v 2)} x M S_{e} x\left|\frac{1}{n_{e f f}}\right|}
$$

3. Menghitung interval kepercayaan untuk eksperimen konfirmasi.

Berdasarkan perhitungan $\mu_{p}$ dan CI, maka dapat dibuat interval kepercayaan dengan persamaan (15).

$$
\mu_{p}-C I \leq \mu_{p} \leq \mu_{p}+C I
$$

4. Membandingkan hasil perhitungan interval kepercayaan pada kondisi optimal dengan konfirmasi.

\section{HASIL DAN PEMBAHASAN}

\subsection{Analisis Faktor Penyebab Masalah}

Berikut ini hasil analisis penyebab masalah pada UD. XY dengan menggunakan diagram sebab akibat yang ditampilkan pada Gambar 2. Berdasarkan Gambar 2, diketahui bahwa terdapat lima faktor utama yang menyebabkan besarnya variasi pada kuat tekan bata ringan. Kelima faktor tersebut terdiri dari faktor manusia, proses, material, lingkungan, dan metode. Pada faktor manusia disebabkan oleh kelalaian pekerja yang diakibatkan kelelahan dan kejenuhan. Faktor material merupakan salah satu penyebab variasi kualitas bata ringan. Faktor selanjutnya, yaitu lingkungan disebabkan tempat kerja di UD. XY memiliki ventilasi terbatas. Faktor metode disebabkan oleh kesalahan mencampur bahan. Faktor proses yang dimaksud adalah lama proses pengeringan. Faktor tersebut akan berpengaruh pada kuat tekan produk bata ringan, apabila waktu lama pengeringan semakin lama maka hasilnya akan semakin baik, dan sebaliknya apabila waktu lama pengeringan hanya sebentar maka kuat tekan produk yang dihasilkan menjadi lebih rendah. 


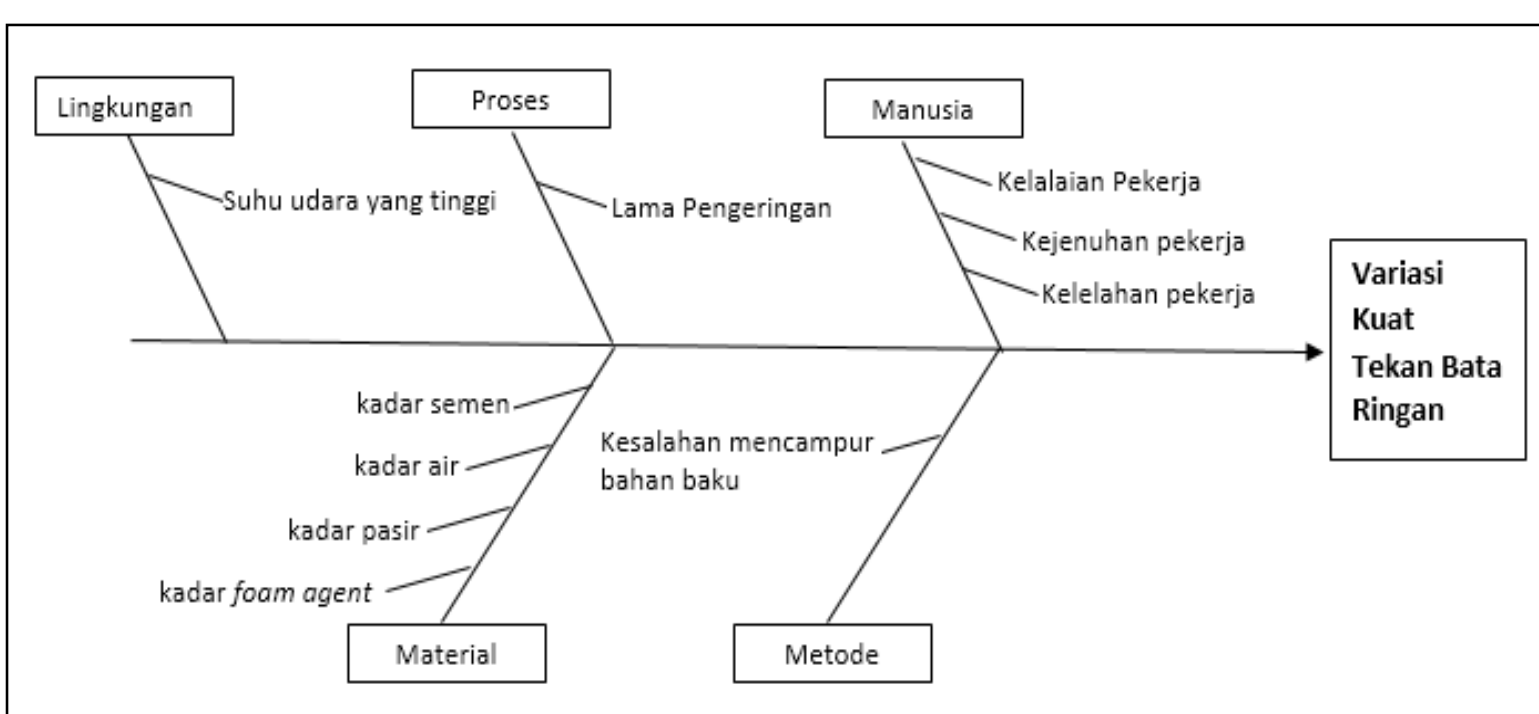

Gambar 2 Diagram Sebab-Akibat

\subsection{Menentukan Faktor-faktor Eksperimen}

Penentuan faktor-faktor eksperimen ini bertujuan untuk menentukan faktor apa saja yang digunakan dalam eksperimen. Penentuan faktor kontrol dilakukan dengan kepala produksi UD. XY sebagai pihak yang paling memahami proses pembuatan bata ringan dan keterbatasan kondisi pabrik. Setelah berdiskusi dengan kepala produksi di UD. XY terdapat dua faktor kontrol yaitu material dan metode. Kedua faktor tersebut merupakan faktor kritis terhadap dimensi kualitas yang dipilih yaitu kinerja kuat tekan bata ringan. Material yang digunakan dalam pembuatan bata ringan yaitu semen, air, pasir dan foam agent sangat berpengaruh terhadap kuat tekan bata ringan. Faktor metode juga dipilih sebagai faktor kontrol. Hal ini dikarenakan penentuan komposisi akan menentukan kuat tekan bata ringan. Sementara itu, faktor-faktor lain seperti lingkungan dan manusia tidak dipilih karena tidak memengaruhi kuat tekan bata ringan. Faktor lama pengeringan sebenarnya juga memengaruhi kuat tekan bata ringan. Akan tetapi berdasarkan diskusi dengan kepala produksi dengan mempertimbangkan waktu penelitian dan kondisi pabrik maka diputuskan untuk menggunakan lama pengeringan mengikuti standar di UD. XY yaitu selama 26 hari.

\subsection{Membuat Level Faktor}

Penetapan level dilakukan dengan bantuan Kepala Produksi di UD. XY. Adapun level yang diberikan untuk beberapa faktor kontrol seperti dijelaskan pada Tabel 2.
Tabel 2. Level Faktor Eksperimen

\begin{tabular}{lcccc}
\hline \multirow{2}{*}{ Faktor } & \multirow{2}{*}{ Kode } & \multicolumn{3}{c}{ Level } \\
\cline { 3 - 5 } & & $\mathbf{1}$ & $\mathbf{2}$ & $\mathbf{3}$ \\
\hline Air & $\mathrm{A}$ & 0,8 & 1 & 1,2 \\
Semen & $\mathrm{B}$ & 1,5 & 2 & 2,5 \\
Pasir & $\mathrm{C}$ & 3 & 3,5 & 4 \\
\hline
\end{tabular}

\subsection{Membuat Orthogonal Array}

Pembuatan orthogonal array diawali dengan menetapkan faktor dan level. Penetapan ini telah dilakukan pada tahap sebelumnya dimana penelitian ini terdiri dari tiga faktor dan tiga level. Setelah faktor dan level ditetapkan, maka dapat dihitung derajat kebebasannya didapatkan 6 derajat kebebasan. Setelah mendapatkan hasil perhitungan derajat kebebasan, maka langkah yang selanjutnya adalah memilih matriks orthogonal array yang sesuai. Notasi orthogonal array yang sesuai adalah $\mathrm{L}_{9}\left(3^{4}\right)$ dimana hal ini menunjukkan bahwa percobaan minimal yang akan dilakukan adalah sebanyak sembilan kali.

\subsection{Pelaksanaan Eksperimen}

Sesuai dengan notasi yang telah ditentukan, jumlah eksperimen yang dilakukan pada penelitian kali ini sebanyak sembilan eksperimen dan direplikasi sebanyak dua kali. Adapun kombinasi eksperimen yang dilakukan akan dibuat dengan menggunakan bantuan perangkat lunak Minitab 16. Tabel 3 menampilkan kombinasi sembilan eksperimen pembuatan bata ringan di UD. XY: 
Tabel 3. Kombinasi Eksperimen $\mathrm{L}_{9}\left(3^{4}\right)$

\begin{tabular}{cccc}
\hline \multirow{2}{*}{ Eksperimen } & \multicolumn{3}{c}{ Faktor } \\
\cline { 2 - 4 } & Air & Semen & Pasir \\
\hline 1 & 1 & 1 & 1 \\
2 & 1 & 2 & 2 \\
3 & 1 & 3 & 3 \\
4 & 2 & 1 & 2 \\
5 & 2 & 2 & 3 \\
6 & 2 & 3 & 1 \\
7 & 3 & 1 & 3 \\
8 & 3 & 2 & 1 \\
9 & 3 & 3 & 2 \\
\hline
\end{tabular}

Tabel 4 menampilkan rancangan yang berisi perbandingan komposisi eksperimen sesuai dengan matriks orthogonal array $\mathrm{L}_{9}\left(3^{4}\right)$ serta konversi penggunaan bahan dalam satuan kilogram (kg).

Berdasarkan eksperimen yang telah dilakukan, total berat keseluruhan bahan sebesar $9 \mathrm{~kg}$ dapat menghasilkan satu buah bata ringan. Pengujian dilakukan terhadap dua buah sampel untuk masing-masing eksperimen, sehingga total bata ringan yang diuji adalah delapan belas buah. Sebelum dilakukan pengujian, bata ringan telah diberi tanda berupa nomor satu sampai sembilan untuk menunjukkan nomor eksperimen. Hasil dari pengujian akan muncul berupa angka dan kemudian akan dicatat sebagai data pengujian. Tabel 5 menunjukkan hasil pengujian bata ringan untuk masing-masing eksperimen.

\subsection{Pengolahan Data Hasil Eksperimen}

Data-data yang telah diperoleh dari hasil eksperimen selanjutnya diolah untuk mendapatkan nilai rata-rata dan signal to noise ratio (SNR) dengan klasifikasi larger the better. Adapun kedua nilai tersebut nantinya akan dilakukan perhitungan ANOVA untuk mendapatkan faktor mana saja yang memiliki pengaruh yang signifikan terhadap kekuatan bata ringan.

Tabel 4. Rancangan Komposisi Eksperimen

\begin{tabular}{ccccccc}
\hline \multirow{2}{*}{ Eksperimen } & \multicolumn{3}{c}{ Perbandingan Komposisi } & \multicolumn{3}{c}{ Konversi } \\
\cline { 2 - 7 } & Air & Semen & Pasir & Air (liter) & Semen (kg) & Pasir (kg) \\
\hline 1 & 0,8 & 1,5 & 3 & 1,358 & 2,547 & 5,094 \\
2 & 0,8 & 2 & 3,5 & 1,142 & 2,857 & 5 \\
3 & 0,8 & 2,5 & 4 & 0,986 & 3,082 & 4,931 \\
4 & 1 & 1,5 & 3,5 & 1,5 & 2,25 & 5,25 \\
5 & 1 & 2 & 4 & 1,285 & 2,571 & 5,142 \\
6 & 1 & 2,5 & 3 & 1,384 & 3,461 & 4,153 \\
7 & 1,2 & 1,5 & 4 & 1,611 & 2,014 & 5,373 \\
8 & 1,2 & 2 & 3 & 1,741 & 2,903 & 4,354 \\
9 & 1,2 & 2,5 & 3,5 & 1,5 & 3,125 & 4,375 \\
\hline
\end{tabular}

Tabel 5. Hasil Pengujian Bata Ringan

\begin{tabular}{ccccc}
\hline Eksperimen & Beban Tekan $(\mathbf{k N})$ & Konversi $\mathbf{( k g})$ & Luas Bidang $\left(\mathbf{c m}^{\mathbf{2}}\right)$ & Kuat Tekan $\left.\mathbf{( k g} / \mathbf{c m}^{2}\right)$ \\
\hline \multirow{2}{*}{1} & 31 & $3.161,320$ & 100,00 & 31,613 \\
& 31 & $3.161,320$ & 101,00 & 31,297 \\
\hline \multirow{2}{*}{2} & 76 & $7.749,872$ & 100,53 & 77,090 \\
& 76 & $7.749,872$ & 100,20 & 77,344 \\
\multirow{2}{*}{3} & 88 & $8.973,536$ & 100,37 & 89,404 \\
& 88 & $8.973,536$ & 100,29 & 89,475 \\
\hline \multirow{2}{*}{4} & 70 & $7.138,040$ & 100,31 & 71,159 \\
& 70 & $7.138,040$ & 100,10 & 99,932 \\
\multirow{2}{*}{5} & 98 & $9.993,250$ & 100,00 & 99,932 \\
\hline \multirow{2}{*}{6} & 98 & $9.993,250$ & 100,00 & 96,487 \\
& 95 & $9.687,340$ & 100,40 & 86,095 \\
\hline \multirow{2}{*}{7} & 95 & $9.687,340$ & 100,81 & 82,112 \\
\multirow{2}{*}{8} & 81 & $8.259,732$ & 100,59 & 29,343 \\
& 81 & $8.259,732$ & 100,49 & 29,439 \\
\hline \multirow{2}{*}{9} & 29 & $2.957,188$ & 100,78 & 39,559 \\
& 29 & $2.957,188$ & 100,45 & 39,669 \\
\hline
\end{tabular}


Tabel 6. Hasil Perhitungan Nilai Mean dan SNR

\begin{tabular}{|c|c|c|c|c|c|}
\hline \multirow{2}{*}{ Eksperimen } & \multicolumn{2}{|c|}{ Hasil Uji Tekan $\left(\mathrm{kg} / \mathrm{cm}^{2}\right)$} & \multirow{2}{*}{ Jumlah } & \multirow{2}{*}{ Mean $(\mu)$} & \multirow{2}{*}{ SNR } \\
\hline & 1 & 2 & & & \\
\hline 1 & 31,613 & 31,297 & 62,910 & 31,455 & 29,953 \\
\hline 2 & 77,090 & 77,344 & 154,434 & 77,217 & 37,754 \\
\hline 3 & 89,404 & 89,475 & 178,879 & 89,440 & 39,030 \\
\hline 4 & 71,159 & 71,309 & 142,468 & 71,234 & 37,053 \\
\hline 5 & 99,932 & 99,932 & 199,864 & 99,932 & 39,994 \\
\hline 6 & 96,487 & 96,095 & 192,582 & 96,291 & 39,671 \\
\hline 7 & 82,112 & 82,194 & 164,306 & 82,153 & 38,292 \\
\hline 8 & 29,343 & 29,439 & 58,782 & 29,391 & 29,364 \\
\hline 9 & 39,559 & 39,669 & 79,228 & 39,614 & 31,956 \\
\hline
\end{tabular}

Tabel 7. Respon Nilai Rata-rata

\begin{tabular}{cccc}
\hline & \multicolumn{4}{c}{ Faktor } \\
\cline { 2 - 4 } & Air $(\mathbf{A})$ & Semen $(\mathbf{B})$ & Pasir $(\mathbf{C})$ \\
\hline 1 & 66,04 & 61,61 & 52,38 \\
2 & 89,15 & 68,85 & 62,69 \\
3 & 50,39 & 75,11 & 90,51 \\
\hline Ranking & $\mathbf{2}$ & $\mathbf{3}$ & $\mathbf{3}$ \\
\hline
\end{tabular}

\subsection{Perhitungan Nilai Rata-rata (Mean) dan Signal to Noise Ratio (SNR)}

Pada bagian ini akan dihitung nilai ratarata (mean) dan Signal to Noise Ratio (SNR) menggunakan rumus (2) dan rumus (4). Tabel 6 menunjukkan data perhitungan mean dan SNR untuk masing-masing eksperimen.

\subsection{Perhitungan ANOVA untuk Nilai Rata- rata \\ Pada bagian ini dilakukan perhitungan} ANOVA untuk nilai rata-rata. Perhitungan akan dilakukan mulai dari perhitungan nilai rata-rata semua eksperimen hingga perhitungan persen kontribusi masing-masing eksperimen.

1. Perhitungan nilai rata-rata untuk setiap level faktor.

Pada tahap ini dihitung nilai rata-rata untuk masing-masing level faktor. Tabel 7 merupakan hasil perhitungan menggunakan bantuan Minitab.

2. Perhitungan total sum of square due to factors

Berdasarkan persamaan (6), didapatkan data untuk perhitungan sum of square due to factors. Tabel 8 berisikan hasil perhitungan sum of square due to factors.

Tabel 8. Hasil Perhitungan Sum of Square due to Factors

\begin{tabular}{lr}
\hline & Total Sum of Square Due To Factors \\
\hline SS $_{\mathbf{A}}$ & $4.566,776$ \\
SS $_{\mathbf{B}}$ & 543,599 \\
SS $_{\mathbf{C}}$ & $4.672,402$ \\
\hline
\end{tabular}

3. Perhitungan nilai rata-rata kuadrat (mean square)

Pada tahap ini akan dilakukan perhitungan terhadap nilai rata-rata kuadrat berdasarkan rumus (8) untuk masing-masing faktor. Adapun perhitungan tersebut dapat dilihat pada Tabel 9.

4. Perhitungan nilai $F_{\text {ratio }}$

Hasil dari perhitungan $F_{\text {ratio }}$ berdasarkan persamaan (9) nantinya akan digunakan untuk menentukan faktor mana saja yang memiliki pengaruh yang cukup signifikan. Tabel 9 juga menampilkan hasil perhitungan $F_{\text {ratio }}$ untuk masing-masing faktor.

5. Tabel perhitungan ANOVA untuk nilai ratarata

Hasil perhitungan ANOVA untuk nilai ratarata yang telah dilakukan akan dirangkum ke dalam satu tabel untuk dianalisis lebih lanjut. Berdasarkan rumus (8), (10), (11), (12), dan (13), Tabel 10 menampilkan perhitungan ANOVA untuk nilai rata-rata.

Dalam menginterpretasikan hasil perhitungan ANOVA, maka akan dilakukan uji hipotesis. Berikut uji hipotesis yang digunakan dalam pengambilan keputusan pada penelitian ini:

1. Air

$H_{0}$ : Tidak ada pengaruh air terhadap kuat tekan bata ringan.

$H_{1}$ : Air berpengaruh terhadap kuat tekan bata ringan.

$\alpha \quad: 0,05(5 \%)$ 
$F_{\text {ratio }}: 9,398$

Kesimpulan: $F_{\text {ratio }}>F_{\text {tabel }}, H_{0}$ ditolak, artinya air memiliki pengaruh terhadap kuat tekan bata ringan.

2. Semen

$H_{0}$ : Tidak ada pengaruh semen terhadap kuat tekan bata ringan.

$H_{l}$ : Semen berpengaruh terhadap kuat tekan bata ringan.

$\alpha \quad: 0,05(5 \%)$

$F_{\text {ratio }}: 4,1407$

Kesimpulan: $F_{\text {ratio }}>F_{\text {tabel }}, H_{0}$ ditolak, artinya semen memiliki pengaruh terhadap kuat tekan bata ringan.
3. Pasir

$H_{0}$ : Tidak ada pengaruh pasir terhadap kuat tekan bata ringan.

$H_{1}$ : Pasir berpengaruh terhadap kuat tekan bata ringan.

$$
\alpha \quad: 0,05(5 \%)
$$

$F_{\text {ratio }}: 9,615$

Kesimpulan: $F_{\text {ratio }}>F_{\text {tabel }}, H_{0}$ ditolak, artinya pasir memiliki pengaruh terhadap kuat tekan bata ringan.

Berdasarkan hasil uji hipotesis di atas,

didapatkan kesimpulan bahwa ketiga faktor yang digunakan dalam eksperimen, yaitu air, semen, dan pasir memiliki pengaruh yang signifikan terhadap kuat tekan bata ringan.

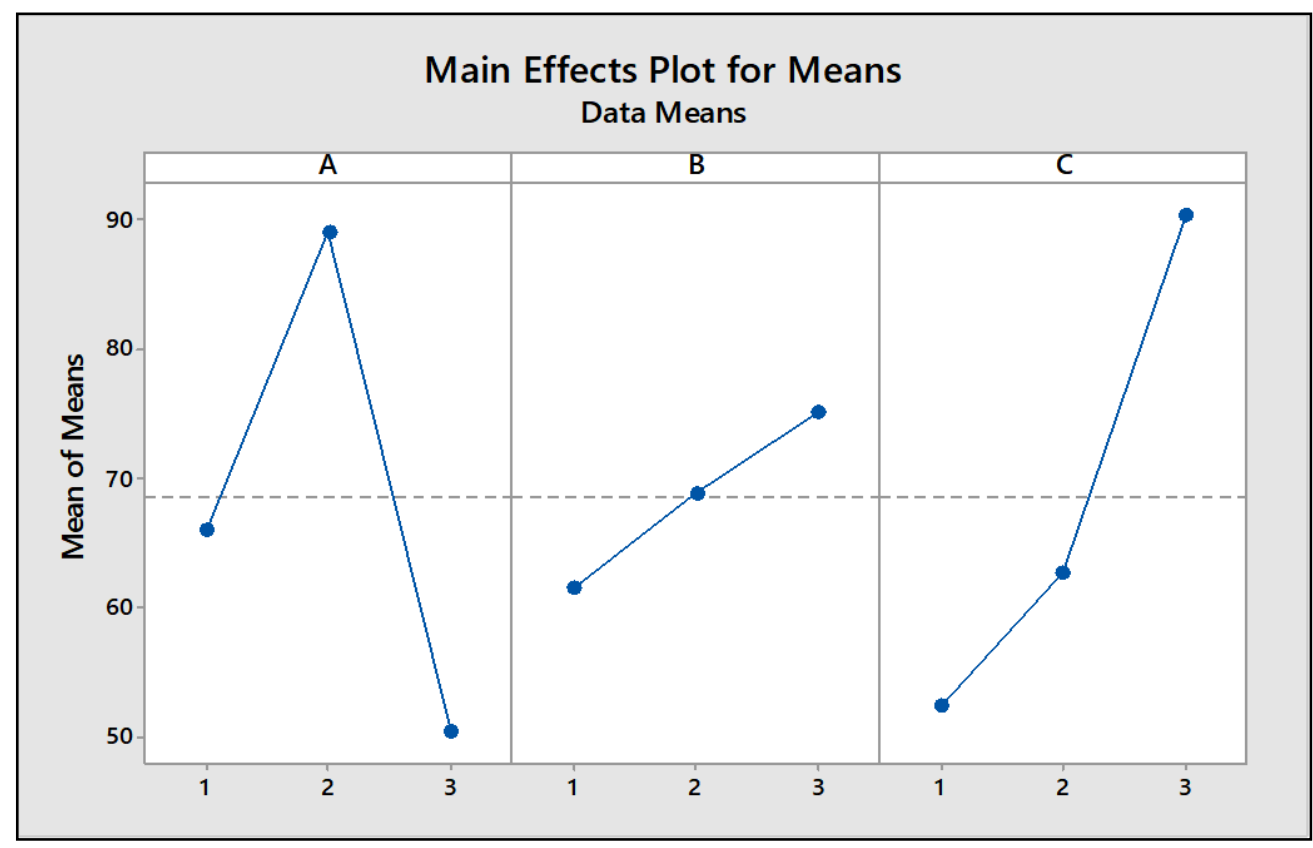

Gambar 3 Grafik Respon Nilai Rata-rata

Tabel 9. Perhitungan Nilai Rata-rata Kuadrat (Mean Square)

\begin{tabular}{cccccc}
\hline Faktor & $\begin{array}{c}\text { Sum of square due } \\
\text { to factors }\left(\mathbf{S S}_{\mathrm{i}}\right)\end{array}$ & $\begin{array}{c}\text { Derajat } \\
\text { Kebebasan } \\
\left(\mathbf{D F}_{\mathbf{i}}\right)\end{array}$ & $\begin{array}{c}\text { Mean Square } \\
\left(\boldsymbol{M S _ { \boldsymbol { i } }}=\frac{\boldsymbol{s S}_{\boldsymbol{i}}}{\boldsymbol{D F}_{\boldsymbol{i}}}\right.\end{array}$ & $\begin{array}{c}\text { Mean of square due to } \\
\text { error }\left(\mathbf{M S}_{\mathrm{e}}\right)\end{array}$ & $\boldsymbol{F}_{\text {ratio }}=\frac{\boldsymbol{M S}_{\boldsymbol{i}}}{\boldsymbol{M S}_{\boldsymbol{e}}}$ \\
\hline $\mathbf{A}$ & $4.566,776$ & 2 & $2.283,388$ & 242,961 & 9,398 \\
$\mathbf{B}$ & 543,599 & 2 & 271,799 & 242,961 & 4,140 \\
$\mathbf{C}$ & $4.672,402$ & 2 & $2.336,201$ & 242,961 & 9,615 \\
\hline
\end{tabular}

Tabel 10. Hasil Perhitungan ANOVA untuk Nilai Rata-rata

\begin{tabular}{|c|c|c|c|c|c|c|c|}
\hline Source & SS & DF & MS & $F_{\text {ratio }}$ & $S S^{\prime}$ & Ratio (\%) & $F_{\text {tabel }}$ \\
\hline $\mathbf{A}$ & $4.566,776$ & 2 & $2.283,388$ & 9,398 & $4.080,854$ & 32,763 & 3,68 \\
\hline B & 543,599 & 2 & 271,799 & 4,140 & 57,679 & 0,463 & 3,68 \\
\hline C & $4.672,402$ & 2 & $2.336,201$ & 9,615 & $4.186,480$ & 33,118 & 3,68 \\
\hline Error & $2.672,580$ & 11 & 242,961 & & $4.130,344$ & 33,161 & \\
\hline$S S_{t}$ & $12.455,357$ & 17 & & & $12.455,357$ & 100,000 & \\
\hline Mean & $84.522,161$ & 1 & & & & & \\
\hline$S S_{\text {total }}$ & $96.932,518$ & 18 & & & & & \\
\hline
\end{tabular}




\subsection{Pooling $U \boldsymbol{p}$}

Pooling up ini merupakan suatu penggabungan faktor dengan signifikansi terendah sebagai eror. Adapun tujuan dilakukan pooling up adalah untuk menghindari estimasi yang berlebihan dan juga untuk meminimalkan kesalahan pada eksperimen yang dilakukan. Pada penelitian ini, faktor yang memiliki nilai SS terkecil dan tingkat signifikansi terendah adalah faktor B. Tabel 11 menjelaskan perhitungan pooling up terhadap faktor B.

Tabel 11. Pooling Up Faktor B

\begin{aligned} & \hline Pooling Up \\ & SS $($ pooled $e)= S S_{e}+S S_{B} \\ & S S($ pooled $e)= 2.672,58+543,599 \\ &$\hline$S S($ pooled $e)= 3.216,179 \\ & D F($ pooled $e)= D F_{e}+D F_{B} \\ & D F($ pooled $e)= 11+2=13 \\ & M S($ pooled $e)= \frac{S S(\text { pooled } e)}{D F(\text { pooled } e)} \\ & M S($ pooled $e)= \frac{3.216,179}{13}=247,398 \\ &$\hline\end{aligned}

Berdasarkan perhitungan pooling up terhadap faktor B yang ditampilkan pada Tabel 11, maka dapat dibuat perhitungan ANOVA untuk nilai rata-rata seperti Tabel 12 .
Berdasarkan Tabel 12 didapatkan bahwa faktor $\mathrm{A}$ dan $\mathrm{C}$ memang memiliki pengaruh atau kontribusi yang signifikan terhadap kuat tekan bata ringan. Sedangkan untuk faktor B sebenarnya juga memiliki kontribusi, namun kontribusinya lebih rendah. Di samping itu juga dapat dilihat persentase kontribusi sebesar $33,766 \%$, dimana hal ini dapat diartikan bahwa semua faktor yang dikatakan signifikan berpengaruh terhadap nilai rata-rata sudah cukup untuk dilibatkan dalam eksperimen (adapun syarat persen kontribusi pada metode Taguchi adalah $\leq 50 \%$ ).

\subsection{Pehitungan ANOVA untuk Nilai SNR} Pada bagian ini dilakukan perhitungan ANOVA terhadap nilai SNR rumus (2) dan rumus (4). Adapun langkah yang dilakukan sama halnya dengan perhitungan ANOVA terhadap nilai rata-rata.

1. Perhitungan nilai rata-rata untuk setiap level faktor.

Pada tahap ini akan dihitung nilai rata-rata untuk masing-masing level faktor. Tabel 13 merupakan hasil perhitungan menggunakan bantuan Minitab.

Tabel 12. Hasil Perhitungan ANOVA Setelah Pooling Up

\begin{tabular}{lrrrrrrr}
\hline Source & \multicolumn{1}{c}{ SS } & \multicolumn{1}{c}{ DF } & \multicolumn{1}{c}{ MS } & $\boldsymbol{F}_{\text {ratio }}$ & \multicolumn{1}{c}{$\boldsymbol{S S}^{\prime}$} & Ratio(\%) & $\boldsymbol{F}_{\text {tabel }}$ \\
\hline $\mathbf{A}$ & $4.566,776$ & 2 & $2.283,388$ & 9,229 & $4.071,98$ & 32,763 & 5,614 \\
$\mathbf{B}$ & 543,599 & - & - & - & - & - & - \\
$\mathbf{C}$ & $4.672,402$ & 2 & $2.336,201$ & 9,443 & $4.177,606$ & 33,540 & 5,614 \\
\hline Error & $2.672,580$ & - & - & - & - & - & - \\
Pooled & $3.216,179$ & 13 & 247,398 & 1 & $4.205,771$ & 33,766 & \\
$\quad \boldsymbol{S S}_{\boldsymbol{t}}$ & $12.455,357$ & 17 & & & $12.455,357$ & 100,000 & \\
Mean & $84.522,161$ & 1 & & & & & \\
$\boldsymbol{S S}_{\text {total }}$ & $96.932,518$ & 18 & & & & & \\
\hline
\end{tabular}

Tabel 13. Respon Nilai SNR

\begin{tabular}{crrrr}
\hline & \multicolumn{3}{c}{ Faktor } \\
\cline { 2 - 5 } & \multicolumn{1}{c}{ Air (A) } & Semen (B) & Pasir (C) \\
\hline 1 & 35,58 & 35,10 & 33,00 \\
2 & 38,91 & 35,70 & 35,59 \\
3 & 33,20 & 36,89 & 39,11 \\
\hline Ranking & $\mathbf{2}$ & $\mathbf{3}$ & $\mathbf{3}$ \\
\hline
\end{tabular}




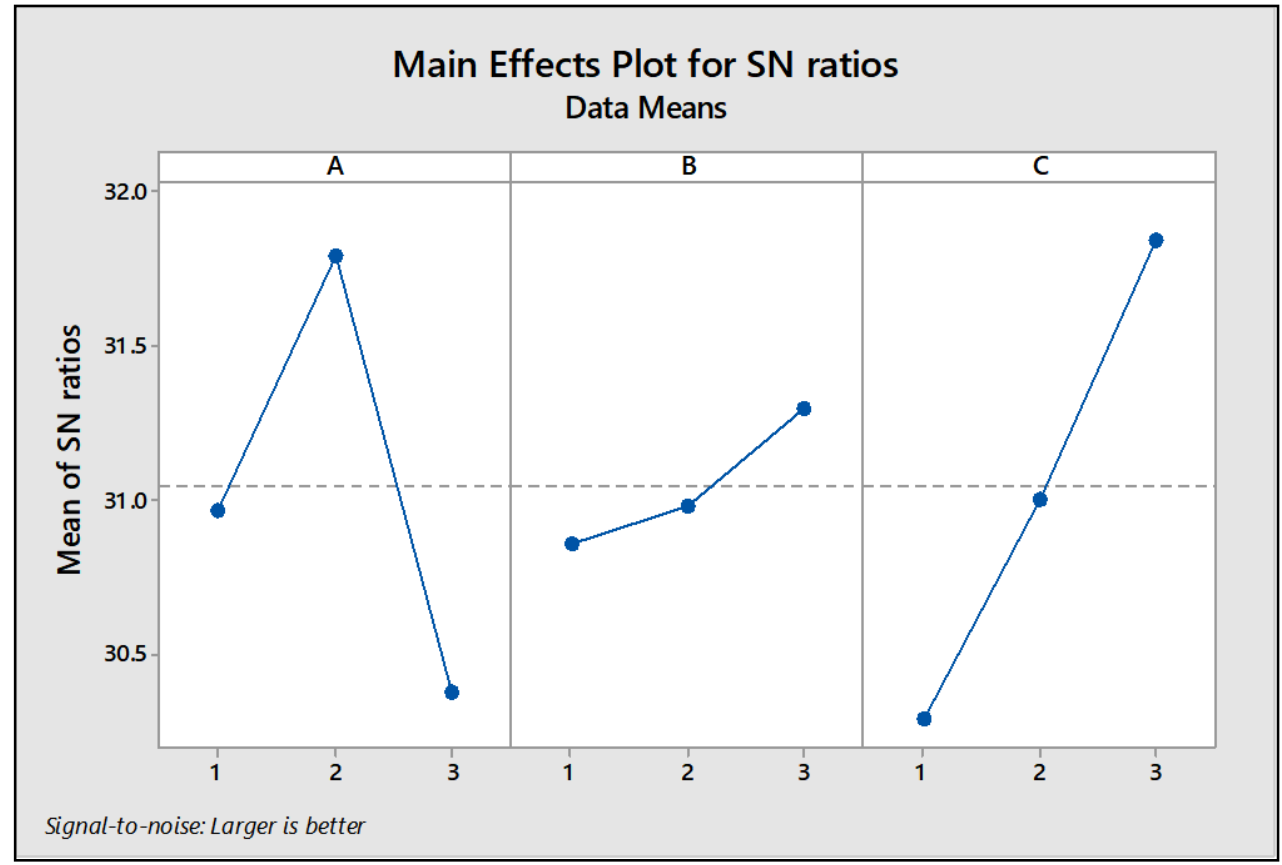

Gambar 4 Grafik Respon Nilai SNR

2. Perhitungan total sum of square due to factors.

Berdasarkan persamaan (6) didapatkan data untuk perhitungan sum of square due to factors. Tabel 14 berisikan hasil perhitungan sum of square due to factors.

Tabel 14. Hasil Perhitungan Sum of Square Due To Factors

\begin{tabular}{lr}
\hline \multicolumn{2}{c}{ Total Sum of Square Due To Factors } \\
\hline SS $_{\mathbf{A}}$ & 49,788 \\
SS $_{\mathrm{C}}$ & 59,015 \\
SS $($ pooled e) & 5,411 \\
\hline
\end{tabular}

3. Perhitungan nilai rata-rata kuadrat (mean square).

Pada tahap ini dilakukan perhitungan terhadap nilai rata-rata kuadrat untuk faktor A dan C saja. Hal ini dikarenakan faktor B telah mengalami tahap pooling up, sehingga faktor B tidak diikutsertakan dalam perhitungan nilai rata-rata kuadrat. Adapun perhitungan tersebut dapat dilihat pada Tabel 15.
Tabel 15. Perhitungan Nilai Rata-rata Kuadrat (Mean Square)

\begin{tabular}{cccc}
\hline Faktor & $\begin{array}{c}\text { Sum of } \\
\text { Square } \\
\text { due to } \\
\text { Factors } \\
\left(\boldsymbol{S S}_{\boldsymbol{i}}\right)\end{array}$ & $\begin{array}{c}\text { Derajat } \\
\text { Kebebasan } \\
\left(\boldsymbol{D} \boldsymbol{F}_{\boldsymbol{i}}\right)\end{array}$ & $\left.\begin{array}{c}\text { Mean } \\
\text { Square } \\
\left(\boldsymbol{M S}_{\boldsymbol{i}}=\right. \\
\boldsymbol{S \boldsymbol { S } _ { \boldsymbol { i } }}\end{array}\right)$ \\
\hline $\mathbf{D}$ & 49,788 & 2 & 24,894 \\
$\mathbf{C}$ & 59,015 & 2 & 29,507 \\
\hline
\end{tabular}

\subsection{Penetapan Setting Level Optimal}

Penetapan setting level yang optimal untuk meningkatkan kualitas produk. Tabel 16 menjelaskan tentang penetapan setting level optimal sesuai dengan perhitungan yang telah dilakukan.

Berdasarkan Tabel 16 dapat dilihat bahwa kombinasi level optimal yang didapatkan adalah $\mathrm{A}_{2}, \mathrm{~B}_{3}$, dan $\mathrm{C}_{3}$. Penetapan setting level optimal pada produk bata ringan tidak tercantum pada tabel rancangan komposisi eksperimen. Oleh karena itu perlu dilakukan eksperimen konfirmasi untuk mendapatkan produk bata ringan yang optimal.

Tabel 16. Setting Level Optimal

\begin{tabular}{ccccc}
\hline Faktor & Kode & Level & Perbandingan & Konversi (kg) \\
\hline Air & A & 2 & 1 & 1,2 \\
Semen & B & 3 & 2,5 & 3 \\
Pasir & C & 3 & 4 & 4,8 \\
\hline
\end{tabular}


Tabel 17 Hasil Pengujian Terhadap Eksperimen Konfirmasi

\begin{tabular}{ccccc}
\hline No. & $\begin{array}{c}\text { Beban Tekan } \\
(\mathbf{k N})\end{array}$ & Konversi Beban $(\mathbf{k g})$ & Luas Bidang $\left(\mathbf{c m}^{2}\right)$ & Kuat Tekan $\left(\mathbf{k g} / \mathbf{c m}^{2}\right)$ \\
\hline $\mathbf{1}$ & 105 & 10707,06 & 101,30 & 105,696 \\
$\mathbf{2}$ & 105 & 10707,06 & 101,45 & 105,540 \\
$\mathbf{3}$ & 105 & 10707,06 & 101,10 & 105,905 \\
$\mathbf{4}$ & 105 & 10707,06 & 101,50 & 105,488 \\
$\mathbf{5}$ & 105 & 10707,06 & 101,60 & 105,384 \\
\hline \multicolumn{5}{c}{ Rata-rata } \\
\hline
\end{tabular}

\subsection{Eksperimen Konfirmasi}

Eksperimen konfirmasi merupakan eksperimen yang dilakukan dengan tujuan untuk melakukan validasi terhadap kesimpulan yang didapatkan dari perhitungan sebelumnya. Eksperimen dilakukan dengan menggunakan rancangan atau kombinasi dari setting level optimal yang telah didapatkan yaitu, $\mathrm{A}_{2}, \mathrm{~B}_{3}$, dan $\mathrm{C}_{3}$. Tabel 17 menampilkan data hasil pengujian terhadap lima buah sampel bata ringan hasil eksperimen konfirmasi.

Lama proses pengeringan produk bata ringan pada eksperimen konfirmasi hanya dilakukan selama empat belas hari hal ini dikarenakan keterbatasan waktu. Setelah mendapatkan data hasil pengujian bata ringan, standar deviasi dan variasi maka akan dihitung nilai rata-rata (mean) dan SNR dengan klasifikasi larger the better.

\subsection{Perhitungan Selang Kepercayaan (Confidence Interval) Terhadap Kondisi Optimal}

Setelah mendapatkan setting level yang optimal, dilakukan perhitungan selang kepercayaan terhadap kondisi optimal tersebut. Perhitungan ini dilakukan untuk dapat membandingkan antara kondisi optimal dengan eksperimen konfirmasi. Perbandingan selang kepercayaan optimal dengan konfirmasi untuk masing-masing nilai rata-rata dan SNR ditunjukkan oleh Gambar 5. Sedangkan perbandingan selang kepercayaan nilai SNR ditunjukkan pada Gambar 6. Gambar tersebut menunjukkan bahwa hasil eksperimen konfirmasi untuk nilai rata-rata dan nilai SNR dapat diterima. Hal ini ditunjukkan oleh selang kepercayaan dimana garis selang kepercayaan eksperimen konfirmasi pada gambar di atas bersinggungan dengan garis selang kepercayaan pada kondisi optimal.
Selanjutnya dilakukan perbandingan antara kuat tekan bata ringan awalan dengan usulan untuk mengetahui apakah terjadi peningkatan kualitas. Tabel 18 membandingkan kuat tekan antara bata ringan awalan dengan bata ringan usulan.

Tabel 18. Perbandingan Kuat Tekan Bata Ringan Awalan dan Usulan

\begin{tabular}{crr}
\hline \multirow{2}{*}{ No. } & \multicolumn{2}{c}{ Kuat Tekan $\left(\mathbf{k g} / \mathbf{c m}^{2}\right)$} \\
\cline { 2 - 3 } & \multicolumn{1}{c}{ Awalan } & Usulan \\
\hline $\mathbf{1}$ & 27,81 & 105,696 \\
$\mathbf{2}$ & 13,25 & 105,540 \\
$\mathbf{3}$ & 17,82 & 105,905 \\
$\mathbf{4}$ & 19,46 & 105,488 \\
$\mathbf{5}$ & 15,14 & 105,384 \\
\hline Rata-rata & 18,696 & 105,603 \\
Standar & 5,62 & 0,203 \\
deviasi & & \\
Varians & 31,68 & 0,041 \\
\hline
\end{tabular}

Setelah mendapatkan kuat tekan bata ringan usulan, dihitung pula standar deviasi dan variasi. Berdasarkan perhitungan kuat tekan bata ringan usulan didapatkan rata kuat tekan yang meningkat signifikan yaitu dari $18,696 \mathrm{~kg} / \mathrm{cm}^{2}$ menjadi $105,603 \mathrm{~kg} / \mathrm{cm}^{2}$ sedangkan standar deviasi juga turun signifikan dari 5,62 (varians 31,68 ) menjadi 0,203 (varians 0,041 ). Varians yang sangat kecil meunjukkan bahwa desain komposisi tersebut bersifat robust. Untuk mengetahui efektifitas dari desain komposisi tersebut perlu dilakukan perbandingan biaya produksi antara komposisi awal dengan komposisi optimal. Kondisi robust tersebut akan efektif jika tidak disertai peningkatan biaya dan lebih efektif jika disertai penghematan biaya produksi dan akan sangat tidak efektif bila biaya produksi meningkat karenanya. 


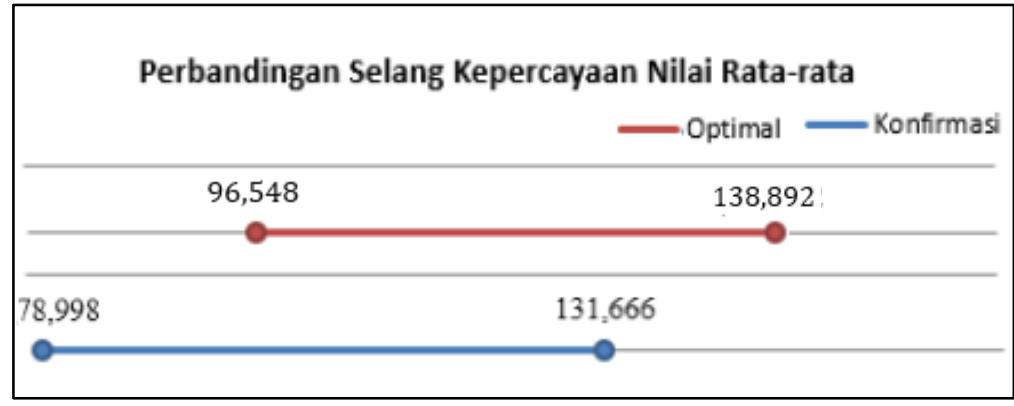

Gambar 5. Perbandingan Selang Kepercayaan Nilai Rata-rata

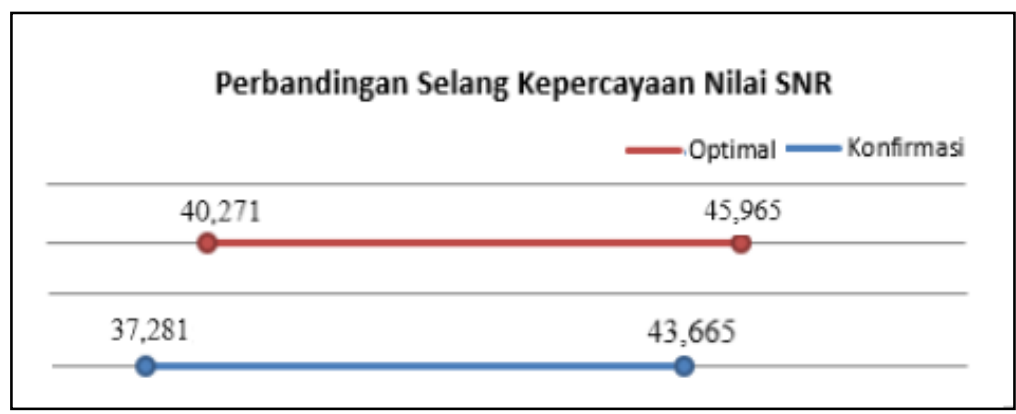

Gambar 6. Perbandingan Selang Kepercayaan Nilai SNR

\section{SIMPULAN}

Untuk mengatasi masalah variasi produk bata ringan yang besar di UD. XY dilakukan perbaikan atau peningkatan kualitas menggunakan metode Taguchi. Dari hasil analisis dengan menggunakan diagram sebab akibat, didapatkan bahwa faktor-faktor yang memengaruhi kualitas bata ringan dibagi ke dalam faktor gangguan dan faktor kontrol. Faktor gangguan yang memengaruhi kualitas bata ringan ini seperti suhu udara yang panas, lama proses pengeringan, kelalaian pekerja. Sedangkan faktor kontrol terdiri dari material dan metode.

Solusi perbaikan untuk meningkatkan kualitas bata ringan di UD. XY adalah dengan melakukan desain eksperimen menggunakan metode Taguchi Adapun hasil eksperimen komposisi optimal bata ringan yang didapatkan adalah komposisi air: semen: pasir sebesar 1:2,5:4. Untuk menjamin hasil komposisi tersebut bersifat robust dilakukan eksperimen konfirmasi. Hasil eksperimen konfirmasi menunjukkan rata-rata kuat tekan yang meningkat dan varians yang sangat kecil $(0,041)$ dibandingkan dengan varians kondisi awal $(31,68)$. Kondisi robust tersebut akan efektif jika disertai penghematan biaya produksi dan akan tidak efektif bila biaya produksi meningkat karenanya.

\section{DAFTAR PUSTAKA}

Gaspersz, V. (1994) Metode Perancangan Percobaan. Bandung: Armico.

Gaspersz, V. (2001) Metode Analisis untuk Peningkatan Kualitas. Jakarta: Gramedia Pustaka Utama.

Montgomery, D. C. (2013) Introduction to Statistical Quality Control. 7 ed. Danvers: John Wiley \& Sons.

Müller, C. et al. (2006) "Modul Pelatihan Pembuatan Ubin atau Paving Blok dan Batako." Jakarta: Kantor Perburuhan Internasional. Tersedia pada: https://www.ilo.org/wcmsp5/groups/publ ic/---asia/---ro-bangkok/---ilojakarta/documents/publication/wcms_12 4018.pdf.

Murnawan, H. dan Mustofa (2014) "Perencanaan Produktivitas Kerja dari Hasil Evaluasi Produktivitas dengan Metode Fishbone di Perusahaan Percetakaan Kemasan PT. X," Jurnal Teknik Industri Heuristic, 11(1), hal. 2746.

Prasetya, C., Rahman, A. dan Efranto, R. Y. (2013) "Analisa Desain Eksperimen Pembuatan Batako Berbahan Alternatif Lumpur Lapindo dan Fly Ash dengan Methode Taguchi," Jurnal Rekayasa dan Manajemen Sistem Industri, 1(1), hal. 5765. 
Setyanto, N. W. dan Lukodono, R. P. (2017) Teori dan Aplikasi Desain Eksperimen Taguchi. Malang: UB Press.

Soejanto, I. (2009) Desain Eksperimen dengan Metode Taguchi. Yogyakarta: Graha Ilmu.

Sutiyarno, D. dan Chriswahyudi, C. (2019) "Analisis Pengendalian Kualitas dan Pengembangan Produk Wafer Osuka dengan Metode Six Sigma Konsep DMAIC dan Metode Quality Function Deployment di PT. Indosari Mandiri," Journal of Industrial Engineering and Management Systems, 12(1), hal. 42-51. doi: 10.30813/jiems.v12i1.1535.

Sutoni, A. (2018) "Uji Kuat Tekan dan Daya Serap pada Batako dengan Menggunakan Metode Taguchi," Jurnal Sistem dan
Manajemen Industri, 2(2), hal. 93. doi: 10.30656/jsmi.v2i2.711.

Tiartanaya, B. M. dan Aribowo, B. (2013) "Analysis of Compressive Strength Quality of Aerated Lightweight Concrete Using Taguchi Methods at PT. XYZ," Journal of Industrial Engineering and Management Systems, 6(2), hal. 74-83.

Tjiptono, F. (2012) Strategi Pemasaran. 3 ed. Yogyakarta: Andi.

Triawati, N. (2007) Penentuan Setting Level Optimal untuk Meningkatkan Kualitas Benang Rayon (30r) dengan Eksperimen Taguchi sebagai Upaya Jaminan Atas Spesifikasi Kualitas Benang. Universitas Sebelas Maret. 